\title{
Rebooting Content: Broadcasting Sport and Esports to Homes During COVID-19
}

\author{
Michael M. Goldman \\ University of San Francisco \\ and University of Pretoria
}

David P. Hedlund

St. John's University

\begin{abstract}
Beginning in early March 2020, sport in the United States entered an unprecedented period of hiatus due to the COVID-19 pandemic. The postponement, suspension, and cancellation of live sporting events impacted every professional and amateur sport organization, from the National Basketball Association to the National Association for Stock Car Auto Racing, high school sports to college football, and even esports leagues. Although the abrupt cancellation of live sporting events was disruptive, it did create opportunities for the production of new media and consumption opportunities for sport leagues, teams, and their fans through different types of sport media broadcasts. This commentary examines how the U.S. sport industry developed media content strategies using new, mixed, and rebroadcasted content, across multiple broadcast and streaming platforms, to provide sport consumption opportunities to fans who were largely quarantined at home. This research contributes to the existing scholarship on live and rebroadcasted mediated content, while providing guidance to content owners and rights holders facing uncertainty in the marketplace.
\end{abstract}

Keywords: live content, mixed content, mediatization, rebroadcasting, sport media content

The COVID-19 pandemic has been an "unprecedented" event, and it has the potential to fundamentally impact the sport industry and broader society (Aziz, 2020, para. 3). In addition, the more immediate physical restrictions consumers experienced as a result of the pandemic created opportunities to use different types of sport media broadcasts to maintain relationships between sports and their fans. The theoretical lens most often used to examine the interrelationship between changes in media and communication, as well as changes in culture and society, is mediatization (Couldry \& Hepp, 2013). Mediatization involves longer term changes in either media or society, brought about by changes in the other

Goldman is with the Sport Management Program, University of San Francisco, San Francisco, CA, USA, and the Gordon Inst. of Business Science, University of Pretoria, Johannesburg, South Africa. Hedlund is with the Div. of Sport Management, Collins College of Professional Studies, St. John's University, Queens, NY, USA. Goldman (mmgoldman@usfca.edu) is corresponding author. 
(Fransden, 2016). The process of mediatization within the sport industry has accelerated, has been seen as a symbiotic relationship, and has recently been discussed in the context of a sport media content economy and "sport/media complex" (Borges, 2019, p. 276).

Most recently, Finn (2020) investigated the relationship between media, motorsport, and society, and demonstrated how esports and new media have the potential to change the relationship between sport and its fans. Esports is defined as "a form of sports where the primary aspects of the sport are facilitated by electronic systems; the input of players and teams as well as the output of the esports system are mediated by human-computer interfaces" (Hamari \& Sjöblom, 2017 , p. 213). Due to frequent conflation of terminology, generally speaking, video gaming occurs when one individual plays a video game alone or against the computer, whereas esports exists when two or more individuals play with or against each other via technology (e.g., Internet, local area network). Although mediatization provides a theoretical framework for understanding the interrelationship between sport media and society (Borges, 2019; Finn, 2020), previous research has not examined the nature of this interrelationship during an extended period of almost no live sport broadcasts. Additionally, previous research has called for the further examination of sport media content during off-season periods, when building relationships with fans may be more difficult but when these periods provide an important opportunity for for engagement activities (Achen, Kaczorowski, Horsmann, \& Ketzler, 2018). The socially restrictive response to the COVID-19 pandemic provides a unique opportunity to study the ways in which media and sport organizations adapted to the suspension of scheduled leagues and events in the United States.

\section{Categorizing New Media Content Strategies}

This commentary examines how U.S. sport leagues and colleges developed media content strategies to serve fans in quarantine. According to recent projections from Two Circles (Cutler, 2020), only 53\% of planned sporting events are likely to take place in 2020; and during the month of March 2020, just over 33\% of scheduled events actually happened. Yet despite the ongoing postponement or cancellations of sporting events, this analysis found that sport broadcasts continued during this period, with a combination of new content and multiple types of rebroadcasted content. As expressed in Table 1, we categorize sport broadcasts on a continuum from new content to rebroadcasted content.

\section{New Content}

Sport provides some of the most appealing broadcast content. Live sport broadcasts provide an opportunity to experience sport as a real-time communal viewing experience, where "every viewer knows and understands that what they are watching and experiencing as it unfolds is available in just the same way for every other viewer" (Scannell, 2001, p. 409). The live sport broadcast, however, is separate from the physical event and can be considered to be one step removed from the physical event. In addition, the live broadcast is packaged by the media, 


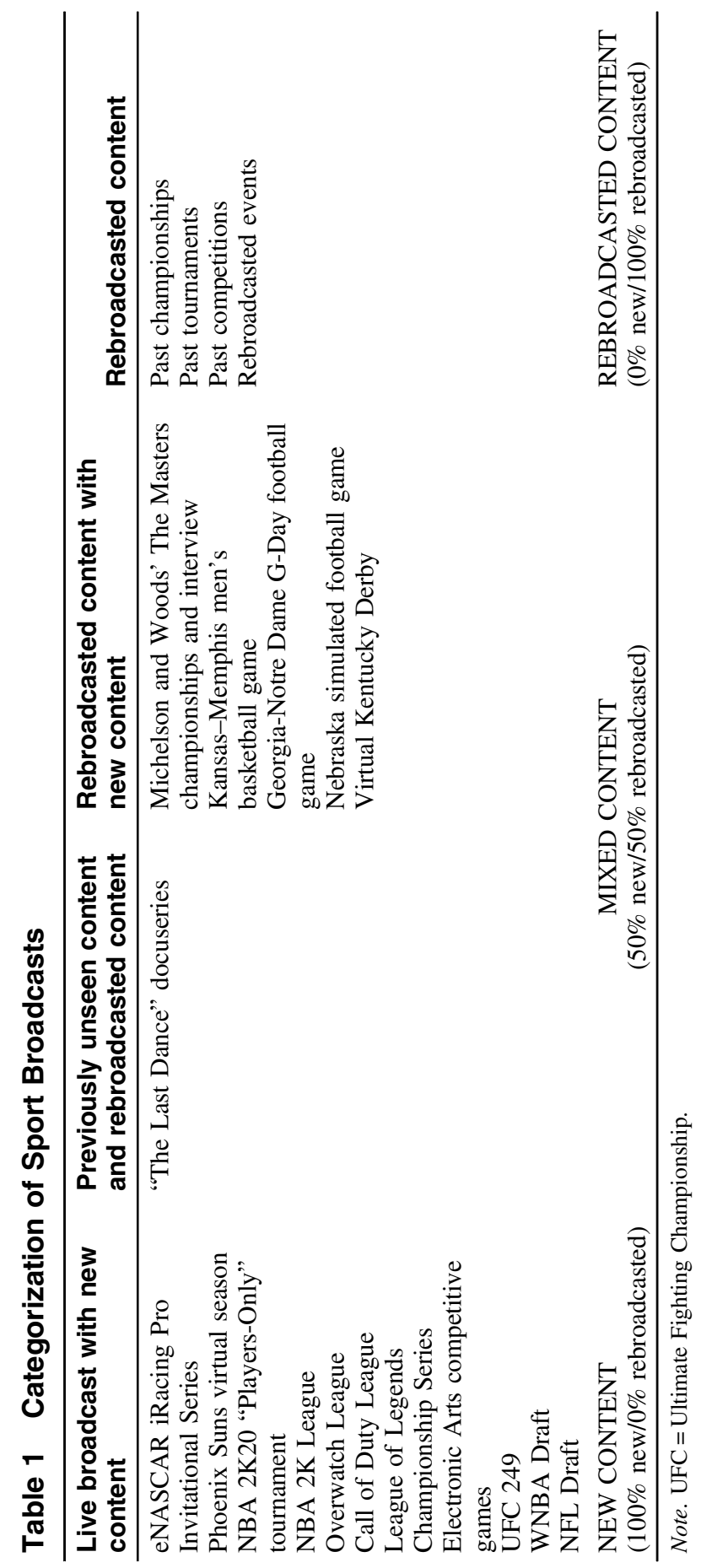


providing one or more versions of the physical event as seen, selected, and produced by the broadcasters. Peters (2001, p. 710) described this broadcaster filter as a witness, who is "authorized to speak by having been present." The live broadcast filter means that a fan at home "is aided and abetted in interpreting the contest by the television camera, which focuses on action deemed important. Announcers add to this focus, as their commentary reinforces and heightens the significance of the contest and the players" (Wenner, 1989, p. 15).

Live sporting events and the resulting near real-time broadcasts consistently dominate television ratings, with $88 \%$ of the top television broadcasts in 2018 being these two types of events (Supan, 2020). The appeal of a live sport broadcast is due to the uncertain, unscripted, and unpredictable nature of the contest, which is not only due to not knowing the outcomes, but also a result of knowing that the outcomes have not yet been decided (Chadwick, 2005). The first category of sport broadcast that our analysis therefore identified was "live broadcast with new content."

There are two primary ways in which this content is composed. The first includes the broadcasting of new esports content. The second includes broadcasting new content created by merging live content set in multiple geographically disparate physical settings into a single media production. For example, participants and fans are located remotely and connected via technology, and social distancing guidelines are observed, or participants are frequently tested for the COVID-19 virus.

On March 17, 2020, 4 days after suspending its season, the National Association for Stock Car Auto Racing (NASCAR) announced the formation of the eNASCAR iRacing Pro Invitational Series as an exhibition, simulation-style esports series, which included drivers from a range of their existing physical racing series, as well as NASCAR dignitaries. The series was hosted on the iRacing online motorsport simulation platform, with each driver participating from home using their own rig. Ben Kennedy, NASCAR's vice president of racing development, framed the series as follows: "Until we have cars back on track, the entire NASCAR community has aligned to provide our passionate fans with a unique, fun and competitive experience on race day" (NASCAR, 2020, para. 3).

Since March 22, 2020, except for the Easter holiday weekend, live eNASCAR iRacing events have been held and broadcast on mainstream television stations, with replays available on YouTube. An average of over 1 million people watched each of the seven live race broadcasts, with NASCAR and Fox Sports ending the series having achieved six of the seven most watched esports programs in U.S. television history (Stern, 2020). The physical NASCAR season resumed on May 17, 2020 at the Darlington Raceway in South Carolina, after the state's governor announced the end of the state's stay-at-home order.

The National Basketball Association (NBA) also embraced esports in its efforts to provide new and live sport media content during March, April, and May of 2020, after suspending its season on March 11, 2020. The first set of activities included the Phoenix Suns playing a virtual season. The virtual season began with an NBA $2 \mathrm{~K}$ game between Phoenix and Dallas on March 13, 2020. The game garnered a peak viewership of over 12,500 people, and during the game, it was one of the top 10 live channels on the esports streaming platform, Twitch (Olson, 2020). The Phoenix Suns franchise quickly created a Twitch channel and hired a professional $2 \mathrm{~K}$ gamer to create their NBA $2 \mathrm{~K}$ team, which included a number of physical NBA players 
from the existing Phoenix Suns roster. The Phoenix Suns streamed 17 games on Facebook, Twitter, and Twitch, reportedly reaching 7.9 million views (Cunningham, 2020). Halfway through the virtual season, the franchise began broadcasting the games streamed in Twitch live on the radio, including the involvement of their regular play-by-play announcer and color analysts. Forbes' Christina Settimi described the Phoenix Suns' sport media experiment as:

That's how professional basketball looks under a national coronavirus lockdown as fans deprived of their favorite showdowns go online for a fix ... . It's yet another indication that the pandemic, while currently putting the global economy on ice, could be leading to massive shifts in consumer patterns and trends. (Settimi, 2020, para. 2)

The NBA's second approach to new and live sport media content was an NBA 2K20 "Players-Only" charity tournament, which took place from April 3-11, 2020. Sixteen NBA players participated in the NBA $2 \mathrm{~K}$ tournament, with matchup seeds determined by a player's respective rating in the game. The online games were broadcasted live on ESPN and also streamed on YouTube, Facebook, Twitter, and Twitch. Jason Argent, NBA 2K's senior vice president for sports strategy and licensing, stated:

The most important thing to us though is the ability to bring some competitive basketball and some light-hearted fun back to audiences around the world right now ... we're pretty delighted by the reach that we've been able to achieve, including becoming ESPN's most-watched esports broadcast in history. (Greif, 2020, para. 5-7)

The third activity through which the NBA provided new and live sport media content was the tip-off of the third season of the NBA 2K League on May 5, 2020. Unlike the Phoenix Suns' virtual season and the once-off NBA 2K20 "PlayersOnly" charity tournament, the NBA 2K League is an organized competition of 23 teams, in which the games are streamed live on Twitch and YouTube Gaming. The 2020 season began remotely as a result of the players being in quarantine, with the expectation that the games will be hosted in a New York venue for up to 200 spectators later in the season. The NBA 2K League Managing Director, Brendan Donohue, hoped that "the excitement of NBA $2 \mathrm{~K}$ League competition provides both new and returning fans with a fun way to stay connected and engage with our league during these unprecedented times" (Garcia, 2020, para. 5).

In addition to the NBA 2K League, a number of other esports leagues canceled physical live events and shifted to online-only competitions, including the Overwatch League, Call of Duty League, League of Legends Championship Series, and Electronic Arts' live events for its competitive games. Although the majority of esports action has always been generated within the online game, the inability to bring all players, referees, and staff to a central studio negatively impacted broadcast quality and raised questions about integrity. Avi Bhuiyan, vice president of product development for esports services company Popdog, argued: "There are a lot of things that you can't control when you have competitions played online ... . There's actually tons of things people can do with their peripherals to manipulate the outcome of a game, or there's risk to the servers" (Ashton, 2020, para. 10-11). 
In contrast to the broadcasting of esports played online in the previous examples, the live broadcasting of a new physical event during the COVID-19 period involved the Ultimate Fighting Championship (UFC). The travel and public gathering restrictions in New York forced the UFC 249 event, originally scheduled for April 18, 2020, to be relocated to a California location. After reported political pressure, the event was postponed indefinitely. By late April, UFC 249 had found a new home in Florida, after that state's governor designated sport and entertainment workers and businesses as essential (Brookhouse, 2020). UFC 249 was hosted on May 9, 2020, with only essential staff in attendance, substantial COVID-19-related safety measures, and no fans, making the UFC the first major sports organization to restart physical operations in the United States. An ESPN statement read: "Sports play an important role in people's lives and can bring moments of escape in challenging times. We look forward to bringing UFC to fans again" (Okamoto, 2020, para. 8). The main event on May 9, 2020 averaged 1.466 million viewers, with at least another 500,000 viewers via ESPN+ (Ourand, 2020).

In addition to new and live competitive sport content, the Women's National Basketball Association (WNBA) Draft and National Football Association (NFL) Draft events were shifted to a fully online and virtual format. On April 17, 2020, the WNBA hosted its most-watched draft event in 16 years, with an average of 387,000 viewers on ESPN, 6.5 million video views, and 1.3 million minutes watched on the WNBA and NBA social media channels (WNBA, 2020). The virtual NFL Draft followed on April 23-25, 2020, reaching a record 55 million viewers on ABC, ESPN, NFL Network, ESPN Desportes, and digital channels (ESPN, 2020c). Similar to the WNBA, the NFL was able to access direct video feeds from draft prospects for the broadcast production, as well as feeds from NFL head coaches, general managers, and fans. NFL Commissioner, Roger Goodell, captured the sport and social meaning of these events:

This Draft is the latest chapter in the NFL's storied history of lifting the spirit of America and unifying people. In addition to celebrating the accomplishments of so many talented young men, we were pleased that this unique Draft helped shine a light on today's true heroes - the healthcare workers, first responders, and countless others on the front lines in the battle against COVID-19. (ESPN, 2020c, para. 5)

\section{Mixed Content}

The second category of live sport identified in this research is "mixed content." Mediatization research has indicated that match highlights, interviews, intimate moments with players, and behind-the-scenes content are among the most attractive content, after the broadcasting of the live game itself (Borges, 2019). During a quarantine period with a limited number of live sporting events, broadcasts of recorded content or past sporting events could provide a similar "simultaneous communal viewing" experience (Whannel, 2009, p. 2016). More broadly, nostalgia and memories that are invoked are important concepts to sport fans (Summers, 2001). The sport media content identified in this category includes a combination of a live broadcast with additional archival and, in some cases, previously unseen, content. There are two primary ways in which this content is composed. The first 
includes the broadcasting of unseen, often archival, footage, interspersed with new interviews with subjects and participants. The second includes a merging of live and archival content together. For example, new and live spoken commentary can be produced and overlaid on archival video content.

Example of previously unseen content and rebroadcasted content. One of the most popular and spoken-about mixed content broadcasts during this period was the 10-part docuseries "The Last Dance" about the 1997-1998 Chicago Bulls season and Michael Jordan's career. The series included unseen archival footage and recent anecdotes from Jordan's former coaches, teammates, and friends, as well as excerpts of an interview with Jordan recorded in 2000. Due to the quarantine, ESPN announced a change to the originally scheduled broadcast in June 2020, which would have coincided with the NBA Finals:

As society navigates this time without live sports, viewers are still looking to the sports world to escape and enjoy a collective experience ... we hope it can serve as a unifying entertainment experience to fill the role that sports often play in our lives, telling a story that will captivate everyone, not just sports fans. (ESPN, 2020a, para. 4)

The premieres of the first six episodes of "The Last Dance" set ratings records for ESPN documentaries, averaging 5.8 million viewers, while rebroadcasts and on-demand viewing more than doubled this reach by early May (NBA, 2020).

Examples of rebroadcasted content with new content. In terms of the second type of mixed content (i.e., live and recorded content merged together into a new broadcast offering), the most prominent example was the CBS rebroadcast of Phil Mickelson's first win at the 2004 Masters on April 11, 2020, and a recounting of Tiger Woods' 2019 Masters Championship on April 12, 2020 (Porter, 2020). Both of these broadcasts included new interviews with both Phil Mickelson and Tiger Woods, as both players respectively recounted these events with broadcaster Jim Nantz, who commented: "We want the presentations to be as stimulating as possible and having Phil and Tiger talk about their wins as they watch the old broadcasts is pure gold for the viewers" (Yocom, 2020, para. 8).

In addition, on Sunday, March 22, 2020, CBS rebroadcasted the 2008 National Collegiate Athletic Association (NCAA) Division 1 Men's Basketball championship game between the University of Kansas and the University of Memphis. The 2020 edition of the "March Madness" tournament was canceled on March 12, 2020. The 2008 Kansas-Memphis rebroadcast was part of nine classic NCAA tournament games that CBS included in their weekend programming schedule. For the Kansas-Memphis rebroadcast, the Memphis coach, Bill Self, and a number of his 2008 players live tweeted during the broadcast, sharing humorous commentary and reflections to add to the entertainment of the game. Self concluded his $2 \mathrm{hr}$ of tweeting with the message: "What a game. What a team what a group of individuals. They spoiled us. What a privilege to be their coach" (Self, 2020).

Similarly, the University of Georgia's annual spring football scrimmage scheduled for April 18, 2020, was canceled due to COVID-19 concerns and reconstituted as a virtual G-Day. Georgia's program for the afternoon included the SEC Network rebroadcasting the 2019 game between Notre Dame and Georgia, 
with the head coach, Kirby Smart, live-tweeting his commentary during the game. The 2019 game was also broadcast on Facebook Live, with live commentary from the existing Georgia Football radio crew (Walsh, 2020).

In contrast to the previous three examples of rebroadcasting archival content with some new content, this research identified two examples of content that combined a simulation of replayed sport, with new content. Nebraska's annual Red-White Football Spring Game, which had previously attracted approximately 85,000 people, was scheduled for April 18, 2020. The Nebraska Athletic Department responded by broadcasting an Xbox-simulated NCAA Football 14 video game on April 18, 2020, using rosters made up of legendary Nebraska players (Gabriel, 2020). The first half of the game was played as a computer simulation, followed by two current Nebraska players controlling the second half plays. More than 22,000 fans viewed the broadcasting of the production on Facebook, Twitter, and Twitch, which was called a few days before by well-known sport radio broadcasters Matt Davison and Greg Sharpe, and included a halftime interview with former Nebraska coach Tom Osborne talking about the historic 1995 spring game (ESPN, 2020b).

Another example of a mixed live broadcast with replayed content was the virtual Kentucky Derby, which was held on May 2, 2020. For this event, using historical performance data from 13 Triple Crown winners, in combination with probability modeling, a computer-generated video of the Kentucky Derby was produced of the possible results if all 13 winners were put side by side in a single race (Associated Press, 2020). In the end, according to the mathematical results, and as shown live in the computer-generated video, Secretariat overtook Seattle Slew down the stretch to win the virtual Kentucky Derby.

\section{Rebroadcasted Content}

The last type of programming identified in this research was the rebroadcasting of past and historical sporting events. For the purposes of this research, rebroadcasting was defined as the broadcasting of content that had previously aired and referred to the use of ready-to-broadcast archival or historical footage. Due to the ease with which previously recorded and archival content can be rebroadcasted, the majority of sport programming during COVID-19 fell into this category. Broadcasters are known to maintain extensive and digitally cataloged archives of content, which are often used to fill programming blocks or when sporting events are postponed or canceled. Although rebroadcasted content may hold nostalgic and sentimental value for some (Heetae, Ramshaw, \& Norman, 2014), the lack of an uncertain outcome or any new content means that it is only a short-term or stop-gap solution. Whenever possible, new content that facilitates the audience's learning of new information, even in the case of an event they have previously watched, is likely to increasingly engage consumers.

\section{Conclusion}

This commentary has examined how U.S. sport leagues, colleges, and broadcasters have provided sport consumption opportunities during the first 3 months of 
pandemic-related restrictions. These media content strategies have included live broadcasts, with varying levels of new content and rebroadcasted content, such as archival and enriched content. The evidence from this unique context reinforces the important role that sport media content plays in culture and society. For sport organizations wanting to meet the sport media needs of their fans, this research suggests new ways to create, combine, and distribute content. Specifically, there is an opportunity to play typically physical games online as esports, or to intersperse archival and new content in hybrid productions and merge recorded content with live commentary and enriched content. In addition, there is an opportunity to simulate game replay and combine live or recorded elements of new content on television, streaming, radio, or social media platforms. As sports in the U.S. return to physical competition, the categorization of sport content developed in this research provides additional opportunities for content owners and rights holders to enhance their post-COVID-19 media content strategies.

\section{References}

Achen, R.M., Kaczorowski, J., Horsmann, T., \& Ketzler, A. (2018). Exploring off-season content and interaction on Facebook: A comparison of U.S. professional sport leagues. International Journal of Sport Communication, 11(3), 389-413. doi:10.1123/ijsc. 2018-0013

Ashton, G. (2020, March 20). Online matches offer esports a lifeline, but quality and fairplay are a challenge. The Esports Observer. Retrieved from https://esportsobserver.com/ esports-online-play-challenges/

Associated Press. (2020, May 2). Secretariat overtakes Seattle Slew down the stretch to win virtual Kentucky Derby. Retrieved from https://www.espn.com/horse-racing/story/_ id/29127439/secretariat-overtakes-seattle-slew-stretch-win-virtual-kentucky-derby

Aziz, S. (2020, March 4). Global sports face 'unprecedented' test amid coronavirus outbreak. Al Jazeera News. Retrieved from https://www.aljazeera.com/news/2020/03/globalsports-face-unprecedented-test-coronavirus-outbreak-200303195953135.html

Borges, F. (2019). Soccer clubs as media organizations: A case study of Benfica TV and PSG TV. International Journal of Sport Communication, 12(2), 275-294. doi:10. 1123/ijsc.2019-0001

Brookhouse, B. (2020, April 29). UFC 249: Five things to know for newly scheduled PPV event and how we got here. CBS Sports. Retrieved from https://www.cbssports.com/ $\mathrm{mma} /$ news/ufc-249-five-things-to-know-for-newly-scheduled-ppv-event-and-how-wegot-here/

Chadwick, S. (2005). Sports marketing: A discipline for the mainstream. International Journal of Sports Marketing \& Sponsorship, 7(1), 7.

Couldry, N., \& Hepp, A. (2013). Conceptualizing mediatization: Contexts, traditions, arguments. Communication Theory, 23(3), 191-202. doi:10.1111/comt.12019

Cunningham, C. (2020, April 17). In a world without sports, Suns provide creative solution to unite fans via online gaming. Phoenix Suns. Retrieved from https://www.nba.com/suns/ features/world-without-sports-suns-provide-creative-solution-unite-fans-online-gaming\#

Cutler, M. (2020, April 20). Covid-19 set to halve 2020 sports calendar-New analysis. Two Circles. Retrieved from https://twocircles.com/us-en/articles/covid-to-halve-2020sports-calendar/

ESPN. (2020a, March 31). Michael Jordan series on ESPN, 'The Last Dance,' moved up to April. Retrieved from https://www.espn.com/nba/story/_/id/28974799/michaeljordan-series-espn-moved-april 
ESPN. (2020b, April 18). Nebraska legends shine in virtual spring game. Retrieved from https://www.espn.com/college-football/story/_/id/29058307/nebraska-legends-shinevirtual-spring-game

ESPN. (2020c, April 26). Virtual NFL draft shatters records with 55 million viewers. Retrieved from https://www.espn.com/nfl/story/_/id/29101466/virtual-nfl-draft-draws55-million-viewers-league-says

Finn, M. (2020). From accelerated advertising to Fanboost: Mediatized motorsport. Sport in Society. Advance online publication. doi:10.1080/17430437.2019.1710131

Fransden, K. (2016). Sports organizations in a new wave of mediatization. Communication \& Sport, 4(4), 385-400. doi:10.1177/2167479515588185

Gabriel, P. (2020, April 18). What's it like to call a virtual spring game? Davison, Sharpe give insight into unique setup. Lincoln Journal Star. Retrieved from https://journalstar.com/ sports/huskers/football/whats-it-like-to-call-a-virtual-spring-game-davison-sharpe-giveinsight-into-unique/article_49dd8a4b-afef-5720-80f8-d14c9bda834c.html

Garcia, J. (2020, April 27). NBA 2K League 2020 season set to start remote gameplay in May. WOAI. Retrieved from https://news4sanantonio.com/sports/spurs-zone/nba-2kleague-2020-season-set-to-start-remote-gameplay-in-may

Greif, A. (2020, April 10). 'NBA 2K' Players Tournament could be more than one-time event. Los Angeles Times. Retrieved from https://www.latimes.com/sports/clippers/ story/2020-04-10/nba-2k-players-tournament-could-be-more-than-one-time-event

Hamari, J., \& Sjöblom, M. (2017). What is eSports and why do people watch it? Internet Research, 27(2), 211-232. doi:10.1108/IntR-04-2016-0085

Heetae, C., Ramshaw, G., \& Norman, W.C. (2014). A conceptual model for nostalgia in the context of sport tourism: Re-classifying the sporting past. Journal of Sport \& Tourism, 19(2), 145-167. doi:10.1080/14775085.2015.1033444

NASCAR. (2020, March 17). NASCAR, iRacing introduce eNASCAR iRacing Pro Invitational Series. Retrieved from https://www.nascar.com/news-media/2020/03/ 17/nascar-iracing-introduce-enascar-iracing-pro-invitational-series/

NBA. (2020, May 4). 'The Last Dance' continues to set ratings records for ESPN. Retrieved from https://www.nba.com/article/2020/05/04/last-dance-ratings-continue-impressiverun-official-release

Okamoto, B. (2020, April 24). UFC schedules three fight cards, led by UFC 249, on May 9 in Florida with no fans. ESPN. Retrieved from https://www.espn.com/mma/story/_/id/ 29094417/ufc-schedules-three-fight-cards-led-ufc-249-9-florida-no-fans

Olson, K. [@KellanOlson]. (2020, March 13). @Suns' first Twitch stream of the games left on the schedule via playing NBA2K was a tremendous success [Tweet]. Twitter. Retrieved from https://twitter.com/KellanOlson/status/1238635183546363906

Ourand, J. [@Ourand_SBJ]. (2020, May 12). UFC TV numbers look good from Saturday. * ESPN averaged 1.466 million viewers from 8-10pm. * Estimates have another 500,000 [Tweet]. Twitter. Retrieved from https://twitter.com/Ourand_SBJ/status/12602099 19338467333

Peters, J.D. (2001). Witnessing. Media, Culture and Society, 23(6), 707-723. doi:10.1177/ 016344301023006002

Porter, K. (2020, April 10). Masters Rewind: Reliving the stunning 2019 Masters with champion Tiger Woods, one year later. Retrieved from https://www.cbssports.com/ golf/news/masters-rewind-reliving-the-stunning-2019-masters-with-champion-tigerwoods-one-year-later

Scannell, P. (2001). Authenticity and experience. Discourse Studies, 3(4), 405-411. doi: $10.1177 / 1461445601003004005$

Self, B. [@CoachBillSelf]. (2020, March 22). What a game. What a team what a group of individuals. They spoiled us. What a privilege to be their [Tweet]. Twitter. Retrieved from https://twitter.com/CoachBillSelf/status/1241786860109791243 
Settimi, C. (2020, March 20). The NBA's Coronavirus shutdown led the Phoenix Suns into a virtual arena. When they drew 3 million fans, the sports world took note. Forbes. Retrieved from https://www.forbes.com/sites/christinasettimi/2020/03/20/the-nbascoronavirus-shutdown-led-the-phoenix-suns-into-a-virtual-arena-when-they-drew-3million-fans-the-sports-world-took-note/\#28e37aca74b8

Stern, A. [@A_S12]. (2020, May 12). @FoxSports finished the Pro Invitational Series with 688,000 viewers for Saturday's iRacing event from virtual North Wilkesboro [Tweet]. Twitter. Retrieved from https://twitter.com/A_S12/status/1260225797383749632? $\mathrm{s}=20$

Summers, J., Johnson, M., \& McColl-Kennedy, J. (2001). Invoking the past: Exploring nostalgia's relevance to sport consumption. Asia Pacific Advances in Consumer Research, 4, 108-113.

Supan, J. (2020, March 9). TV is all about sports now: How live games dominate television. Allconnect. Retrieved from https://www.allconnect.com/blog/sports-dominate-live-tv

Walsh, A. (2020, April 13). Georgia football to hold virtual G-Day. The Red \& Black. Retrieved from https://www.redandblack.com/coronavirus/georgia-football-to-holdvirtual-g-day/article_7d9b8776-7d9d-11ea-9182-0b705fee5cf2.html

Wenner, L.A. (1989). The research agenda. In L.A. Wenner (Ed.), Media, sports and society (pp. 13-48). Newbury Park, CA: Sage.

Whannel, G. (2009). Television and the transformation of sport. The Annals of the American Academy of Political and Social Science, 625(1), 205-218. doi:10.1177/ 0002716209339144

WNBA. (2020, April 21). WNBA delivers most-watched draft in 16 years. Retrieved from https://www.wnba.com/news/wnba-delivers-most-watched-draft-in-16-years/

Yin-Poole, W. (2020, March 14). EA cancels all live events for its competitive games and asks staff to work from home because of coronavirus pandemic. Eurogamer. Retrieved from https://www.eurogamer.net/articles/2020-03-14-ea-cancels-all-live-events-forits-competitive-games-and-asks-staff-to-work-from-home-because-of-coronaviruspandemic

Yocom, G. (2020, April 8). Jim Nantz is just like you-A disappointed golf fan missing this week's Masters. Golf Digest. Retrieved from https://www.golfdigest.com/story/jimnantz-is-just-like-you-a-disappointed-golf-fan-missing-this-weeks-masters 